
\title{
28 Research Square \\ Contract Farming, Social Trust, And Cleaner Production Technology Adoption By Broiler Farmers In China
}

Hui Mao

Shaanxi Normal University

Yong Fu

Shaanxi Normal University

\section{Guangqiao Cao ( $\nabla$ caoguangqiao@126.com )}

Nanjing Institute of Agricultural Mechanization Ministry of Agriculture and Rural Affairs

https://orcid.org/0000-0002-9364-3376

\section{Shaojian Chen}

Shaanxi Normal University

\section{Research Article}

Keywords: Contract Farming, Contract Terms, Social Trust, Institutional Trust, Interpersonal Trust, Cleaner Production

Posted Date: May 26th, 2021

DOI: https://doi.org/10.21203/rs.3.rs-404406/v1

License: (1) This work is licensed under a Creative Commons Attribution 4.0 International License. Read Full License

Version of Record: A version of this preprint was published at Environmental Science and Pollution Research on August 19th, 2021. See the published version at https://doi.org/10.1007/s11356-021-15934-8. 


\section{Abstract}

Pollution from livestock and poultry is the main source of agricultural non-point-source pollution, which directly affects the rural ecological environment as well as the quality and safety of agricultural products. Based on field experiment data of broiler farmers in China, this paper analyzes the cleaner production behavior of farmers from the perspective of incomplete contracts and social trust. We find that social trust can promote farmers' cleaner production behaviors. Moreover, we find that contract farming (CF) has a significant positive effect on farmers' social trust and cleaner production behaviors. Further analysis indicates that CF not only directly promotes farmers' cleaner production, but can also indirectly promote farmers' cleaner production by improving their interpersonal and institutional trust. Overall, this research offers a new point of view for improving the rural environment and sheds light upon how the government can formulate relevant policies to promote farmers' cleaner production technology adoption.

\section{Introduction}

The deterioration of the rural ecological environment has attracted worldwide attention, and agricultural nonpoint-source pollution (AGNPS) accounts for half of pollution emissions, which count as one of the most serious environmental problems (Babin et al., 2016; Sun et al., 2019; Wu and Lu, 2019; Zou et al., 2020). AGNPS has a serious impact on the rural soil environment, water environmental security, quality safety of agricultural products, food security, and human health (He et al., 2020; Rangel and Vogl, 2019). The increased urgency of this issue has also attracted the attention of government departments. As the first policy statement of China in 2019, "No. 1 Central Document 2019" of the Communist Party of China (CPC) Central Committee, which was jointly issued by the CPC Central Committee and China's State Council on February 19, 2019 , proposed strengthening the governance of rural pollution and ecological and environmental protection as well as tightening the governance of AGNPS. However, although the Chinese government strongly supports actions to reduce AGNPS, it still faces practical challenges in terms of a lack of money, technology, and personnel.

Contract farming[1] has attracted considerable attention over the last decades. Contract farming is also called contract agriculture or order agriculture. Many studies have examined the impact of the contract farming approach. For example, some studies considered the impacts of incomplete contracts[2] (Seidel, 2015). Williamson (1985) and Grossman and Hart (1986) believed that incomplete contracts could cause the risk of "hold-up" in the negotiation process. Antràs (2005) and Seidel (2015) proposed that the "rip off" problem[3] caused by incomplete contracts will affect decision-makers' production behaviors and the proliferation of advanced technologies. Contract theory assumes that the contract is complete, but the contract in reality is incomplete (Herweg et al., 2018; Schmitz, 2019). Acemoglu et al. (2007) found that contracts can reduce transaction costs and promote capital accumulation and the use of new technologies. Cleaner production is a knowledge-and/or capital-intensive technology, and incomplete contracts may expose farmers to the risk of being "hold-up." Such hold-ups may lead to farmer uncertainty surrounding the benefits from adopting cleaner production technology. In such an environment, social trust will become the "lubricant" to promote implementation of the contract, and in the incomplete contract system environment, social trust plays a vital role (Braganza et al., 2020; Shen et al., 2019). The higher the social trust of farmers, the less likely they are to be "ripped-off" after special investment, and the higher the probability of cleaner production behavior. However, 
the existing literature does not discuss the relationship between social trust and cleaner production behavior in the framework of contract farming.

The active cooperation of farmers and the social forces in their operating environment are important factors in rural environment control, which relies on mutual restraint from the rural public (Mariola, 2012; Koutsou et al., 2014). Because farmers are the main body of agricultural production, their participation in controlling agricultural production pollution at the source is the key to rural environmental governance (Cao et al., 2020; Li et al., 2020; Wang et al., 2019). Prior studies have suggested that material capital and human capital are the key factors affecting farmers' production decisions (Azadi et al., 2019; MacLeod et al., 2010). Recent studies also emphasized the importance of formal systems, such as government subsidies (Fisher et al., 2014; Foster and Rosenzweig, 2004; Omotilewa et al., 2019) and contract farming (CF) (Mao et al., 2019; Ton et al., 2018). Moreover, driven by the rapid development of sociology, many scholars argued that public participation, environmental protection appeal, and reputation appeal could effectively promote cleaner production behavior among farmers (Skaalsveen et al., 2020). As an important part of social capital, social trust plays an important role in reducing transaction costs and promoting cooperation (Ben-ner and Putterman, 2009; Bergh and Öhrvall, 2018). However, the existing literature has still overlooked the influence and mechanism of social trust on farmers' cleaner production behavior from the perspective of CF.

Therefore, based on survey data of farmers in Jiangsu Province, China, in 2016, this paper takes broiler farmers as an example to test the impact of social trust on farmers' cleaner production behavior under the system environment of typical incomplete contracts in China. The findings in this paper make following contributions to the literature. We explain the differences in farmers' cleaner production behavior from the innovative perspective of contract farming and social trust, and further investigate the indirect effects of CF on farmers' cleaner production behavior. This study introduces social trust under the condition of an incomplete contract, which allows not only a deep analysis of the mechanism of social trust's effect on farmers' cleaner production behavior, but also an understanding of the mechanism of the impact of incomplete contracts on farmers' cleaner production behavior.

Using the survey data on Chinese broiler farmers has the following advantages. First, following the acceleration of China's agricultural industrialization process, the broiler industry has become one of the most large-scale, organized, and intensive industries in China's animal husbandry sector (Huang et al., 2018). Second, the waste generated in the broiler production process has a serious impact on the rural environment. It is a huge challenge for China to achieve sustainable agricultural development and protect a healthy environment (Chadwick et al., 2015). Third, the face-to-face long-term social relationships in the rural acquaintance society that have been established for a long time in China have caused large inter-regional differences in levels of trust (Luo \& Wang, 2020).

The remainder of the study is structured as follows. Section two presents the theoretical analysis and hypothesis development. Section three describes the economic model, variables, and data. Section four contains the empirical analysis and main findings. Section five reviews the conclusions and discussion.

[1] In this paper, contract farming in this paper refers to contracts under "agribusiness firms + farmers" and "agribusiness firms + farmer cooperative + farmers" modes, including not only contracts of sale, but also production contracts. Agribusiness firms and farmers jointly establish production bases, and agribusiness 
firms provide major production materials and technical services to farmers. Farmers are responsible for production management and their products are purchased by agribusiness firms; production and operation risks are jointly shared according to the contracts.

[2] Incomplete contracts exist because a contract cannot include all possible agreements on everything in advance, and incomplete contracting theory has been successfully applied in fields such as organizational economics, corporate finance, industrial organization, and privatization theory.

[3] The "rip off" problem, which is a well-known problem in economics attributable to incomplete contracts, refers to circumstances where one or both parties have a relationship pertaining to a specific investment, and the other party plunders the investment income/outcome after the engagement due to the incompleteness of the contract. This makes the investor's incentive insufficient in advance (before engagement) and thus results in less final investment than the socially optimal amount.

\section{Theoretical Analysis And Hypothesis Development}

\subsection{Contract farming and cleaner production behavior}

Contract farming can improve the cleaner production level of farmers through several mechanisms. First, contract farming improves farmers' environmental awareness, environmental attitudes, and environmental capabilities, thereby improving farmers' cleaner production behavior (Huong et al., 2020; Meike et al., 2007; Ton et al., 2018).

Second, the contract organization provides technical guidance, technical training, production materials credit, pricing sales, credit, and other services for contracted farmers. In addition, CF can reduce transaction costs and solve market imperfections in linking smallholder farmers to markets (Key and Runsten, 1999), thereby reducing farmers' technology adoption costs (Khan et al., 2019; Mao et al., 2019; Soullier and Moustier, 2018).

Third, CF stipulates the rights and obligations of both parties to the transaction (Bellemare and Bloem, 2018). Contracted enterprises influence the production behavior of farmers (Key, 2013). Due to the strong externalities of farmers' cleaner production behaviors (Giannetti et al., 2020; Zhang et al., 2019), under the constraints of the social environment, contracted enterprises would control farmers' cleaner production behaviors for the sake of the firm's reputation, and they would thus guide and encourage farmers to adopt environment-friendly technologies through training and publicity (Mao et al., 2019; Goeb and Lupi, 2021).

Finally, the enterprise supervises and manages the contracted farmers in the production process so that it can (1) accurately grasp the cleaner production situation of the contracted farmers, and (2) convey the government's cleaner production requirements to the contracted farmers in an accurate and timely manner (Gramzow et al., 2018; Huong et al., 2020). In the context of the modernization of China's agricultural sector, CF not only helps enterprises measure and regulate farmer's farming pollution, but also helps them to supervise and effectively promote farmers' adoption of cleaner production technology (Maertens and Veled, 2017; Mishra et al., 2018). Therefore, the following hypothesis is proposed:

$\mathrm{H} 1$ : CF can promote the cleaner production behavior of farmers. 


\subsection{Contract farming and social trust}

Studies have shown that contracts can increase social trust (Ben-ner and Putterman, 2009; Bergh and Öhrvall, 2018). Contracts can provide a platform for communication between strangers and change the face-to-face long-term social relationship of rural acquaintances. First, contracts provide institutional guarantees for social trust (Rigdon, 2009). Contracts can reduce risks, thereby reducing the irrationality and uncertainty of establishing social trust, and promote the establishment of trust with objective standards and foundations. Second, contracts can expand the scope of trust (Shen et al., 2019). Contracts can expand the trust between relatives, break the restrictions of blood relationships and region, promote trust among strangers in society through transactions, and improve social trust among farmers (Tsai and Hung, 2019). Third, contracts can simplify the process of trust generation. In contractual relationships, the contract's style of recognizing things but not people can eliminate monopolies and entanglement of human relationships and offers greater potential for social integration.

Furthermore, contract organizations can use legal means to eliminate blindness in trust establishment, reduce the costs of trust, and increase farmers' institutional trust in government departments (Rigdon, 2009; Praxmarer-Carus, 2014; Shen et al., 2019; Wuepper and Sauer, 2016). Finally, in the process of agricultural industrialization, the government supports leading enterprises and builds "bridges" and intermediaries to help scattered family-run farmers to enter the market. Contract organizations can reduce information asymmetry through training and guidance and promote farmers' compliance with policies and regulations. They can also boost other aspects of understanding, thereby enhancing farmers' trust in the government. Therefore, we put forward the second hypothesis:

Hypothesis 2: Participating in CF promotes the trust of farmers; that is, compared with non-contracted farmers, contracted farmers have higher degrees of interpersonal and institutional trust.

\subsection{Social trust and cleaner production behavior}

Trust is a key component of social capital. Trust, which refers to someone's feedback behavior based on whether the behavior of others affects moral standards (Chen et al., 2020; Messick et al., 2001), is an expectation of future events. An important type of social capital, it has a strong impact on the production decision-making behavior of farmers (Alpenberg and Scarbrough, 2018; Mariola, 2012). Luhmann (1979) divided trust into institutional trust and interpersonal trust. Institutional trust refers to trust that often relies on legal, political, and other institutional environments and is based on "non-interpersonal" relationships. Generally speaking, trust in village cadres can be considered institutional trust. Interpersonal trust refers to the use of emotion as the bond between people. This type of trust, which mainly occurs in the family and among extended relatives and neighbors, can be divided into closeness and distance (Portes et al., 1993; Tsai and Hung, 2019). Many studies have analyzed the impact of trust on rural environmental governance and generally found that trust has a positive effect on farmers' ecological environmental governance (Prazan, 2014). The higher the level of social trust, the higher farmers' social capital stock will be, which has a positive promoting effect on environmental governance (Cobo-Reyes et al., 2017; Joffre et al., 2020).

This promotion effect happens via several pathways. First, trust affects farmers' environmental governance behaviors through the information-sharing mechanism. Disclosing environmental information reduces 
information costs, which can encourage farmers to better oversee each other's environmental pollution behaviors. More environmental information can help break the "bullwhip effect," i.e., the serious problem of environment pollution caused by asymmetric information and distrust among farmers (Azadi et al., 2019; Dang et al., 2014). Secondly, trust can establish an internal constraint mechanism to influence farmers' environmental governance behavior. Trust can thus be called a "soft constraint." Under the structure of rural social relations, it may be more efficient to construct internal rules (farmers' self-restraint) for the autonomous governance of rural environments (Hartmann et al., 2014). For example, rural waste disposal requires public participation in order to achieve good results, and social trust helps solve the issue of "free-rider" behavior in collective action. Finally, trust can influence the environmental governance behavior of farmers by establishing a cooperative mechanism. Specifically, a high level of trust will reduce transaction costs and thus ultimately promote cooperation (Fukuyama, 1995). Therefore, we hypothesize the following:

Hypothesis 3: Trust can promote the cleaner production behavior of farmers; that is, trust can stimulate farmers to adopt cleaner production technology. The higher the degrees of interpersonal and institutional trust, the higher the probability of cleaner production behavior.

\section{Model, Variables, And Data}

\subsection{Econometric model}

This paper mainly analyzes the impact of $\mathrm{CF}$ and social trust on farmers' cleaner production behavior. The explained variable in this paper is farmers' cleaner production behavior, which is a 0-1 variable. We build the following econometric model:

$Y=a 1+\beta 1 \times$ Contract $+\delta 1 \times X+\mu 1$

Trust $=a 3+\beta 3 \times$ Contract $+\delta 3 \times X+\mu 3$

$Y=a 4+\beta 4 \times$ Contract $+\gamma 4 \times$ Trust $+\delta 4 \times X+\mu 4$ (4)

Where $Y$ represents whether the farmer adopts cleaner production technology. Contract denotes whether the farmer participates in CF. Trust indicates the trust of the farmer, including institutional trust and interpersonal trust. Besides, the control variables are the individual characteristics of the farmer (such as age, family assets, years of education, etc.), farming characteristics (such as technology exchange degree, experience, etc.), and regional characteristic variables.

\subsection{Data collection}

This study selects Jiangsu Province, China as the research area (see Fig. 1). Jiangsu Province is a major poultry meat production province in China. China's well-known breeding enterprises such as Wen's and Lihua, developing broiler breeding industry in Jiangsu area and leading local farmers to raise chickens and become rich. In addition to these leading enterprises, there are many broiler enterprises with different contract models in Jiangsu. The cooperation models between enterprises and farmers are different, which provides a good research sample for contract difference analysis. The contract arrangements are different, which provides a good research sample for empirical analysis in this paper. 
The research team conducted surveys in 11 counties in Jiangsu from March to June 2016, and randomly selected 35 large-scale farmers in each county to conduct a one-to-one survey. The investigator interviewed the head of each sample farmer for 1 hour to obtain the basic characteristics, farming characteristics, production status, contract relationship, and other information about the farmer. Each questionnaire farmer was offered 20 yuan to compensate for loss of work time. In addition, the research team also conducted risk preference and time preference experiments and paid farmers cash in accordance with the results of the experiment. On average, each farmer could receive 50 yuan.[1] A total of 385 valid questionnaires were received, of which 345 were from farmers who farmed broilers with yellow feathers. The specific distribution of sample farmers is as shown in Table 1.

Table 1 Distribution of sample areas

\begin{tabular}{|lllll|}
\hline Southern Jiangsu & Central Jiangsu & Northern Jiangsu & Total \\
\hline $\begin{array}{l}\text { Suzhou, Changzhou, } \\
\text { Zhenjiang }\end{array}$ & $\begin{array}{l}\text { Taizhou, Nantong, } \\
\text { Yangzhou }\end{array}$ & $\begin{array}{l}\text { Suqian, Xuzhou, Lianyungang, } \\
\text { Yancheng, Huaian }\end{array}$ & 11 \\
& $\begin{array}{l}\text { Taicang, Jintan, } \\
\text { Dantu }\end{array}$ & $\begin{array}{l}\text { Jiangyan, Haimen, } \\
\text { Gaoyou }\end{array}$ & $\begin{array}{l}\text { Suyu, Pizhou, Donghai, Dafeng, } \\
\text { Xuyi }\end{array}$ & 11 \\
Observations & 127 & 64 & 154 & 345 \\
\hline
\end{tabular}

\subsection{Specification of variables}

\subsubsection{Explained variable}

This paper takes the broiler breeding process as an example. Using whether the farmers have special sewage treatment equipment or devices, waste (feed bags, veterinary drug vaccine packaging), sick chickens, and feces measure the cleaner production behavior of farmers. Through cluster analysis, the waste treatment methods of farmers are divided into cleaner production and non-cleaner production[2].

\subsubsection{Key explanatory variable}

Contract farming. The contract farmers in this paper refer to the farmers who have signed production contracts with leading enterprises. In this situation, the value of $C$ is 1 . The non-contract farmers are the ones who do not participate in the model. So, the value of $\mathrm{C}$ is 0 . Farmers participating in the production contracts can obtain technical guidance from the enterprise in time. Otherwise, the enterprise will conduct farming norms and requirements for the farmer and supervise the implementation of cleaner production (Acemoglu et al., 2007; Mao et al., 2019). Therefore, farmers who have signed contracts with enterprises are more inclined to cleaner production.

Contract terms. Contract terms mainly refer to the time (unit, month) for signing a single contract between the farmer and the contracting enterprise, which generally includes three months, twelve months, thirty-six months, and one hundred and twenty months. The length of the contract period determines the farmers' behavior expectation, The short-term or uncertain contract term will induce the farmers' short-term behavior in production. The longer the contract period is, the longer the farmers have been engaged in production in the industry. Meanwhile, the higher sunk cost they face, the more incentive they will have to adopt cleaner 
production technology. In order to save transaction costs, enterprises are more willing to provide more technical training and guidance for long-term contracted farmers to promote cleaner production (Gramzow et al., 2018; Mao et al., 2019).

Social trust. Due to the difference in the objects of interpersonal trust and institutional trust, the mechanism of impact on farmers' cleaner production is different (Braganza et al., 2020). This article studies the impact of interpersonal trust and institutional trust on farmers' cleaner production behavior. Trust in relatives and friends (trust1) represents interpersonal trust. Trust in government (trust2) describes institutional trust. Use the following questions to measure: "Do you think your relatives and friends are trustworthy?", "Do you think the local government is trustworthy?". Both questions are ranked in terms of trust intensity (very distrustful, not too trustworthy, generally trustworthy, somewhat trustworthy, very trustworthy).

Table 2 reports the impact of contracts and social trust on farmers' cleaner production behavior. In Table 2, it can be seen that the higher the trust of farmers in relatives and friends and the government, the higher the probability of cleaner production behavior.

Table 2 The impact of contracts and social trust on farmers' cleaner production behaviors

\begin{tabular}{|c|c|c|c|c|c|c|}
\hline & & \multirow[b]{2}{*}{$\begin{array}{l}\text { Level of } \\
\text { trust }\end{array}$} & \multicolumn{2}{|c|}{ Contract farmer } & \multicolumn{2}{|c|}{ Non-contract farmer } \\
\hline & & & $\begin{array}{l}\text { Cleaner } \\
\text { production(\%) }\end{array}$ & $\begin{array}{l}\text { Non-cleaner } \\
\text { production(\%) }\end{array}$ & $\begin{array}{l}\text { Cleaner } \\
\text { production(\%) }\end{array}$ & $\begin{array}{l}\text { Non-cleaner } \\
\text { production(\%) }\end{array}$ \\
\hline & & & 54 & 230 & 6 & 55 \\
\hline \multirow[t]{5}{*}{$\begin{array}{l}\text { Interpersonal } \\
\text { trust }\end{array}$} & \multirow{5}{*}{ trust1 } & $\begin{array}{l}\text { Very } \\
\text { distrustful }\end{array}$ & 0 & 0 & 16.67 & 43.64 \\
\hline & & $\begin{array}{l}\text { Not too } \\
\text { trustworthy }\end{array}$ & 11.11 & 55.65 & 33.33 & 10.91 \\
\hline & & $\begin{array}{l}\text { General } \\
\text { trustworthy }\end{array}$ & 18.52 & 11.74 & 16.67 & 36.36 \\
\hline & & $\begin{array}{l}\text { Somewhat } \\
\text { trustworthy }\end{array}$ & 22.22 & 25.65 & 16.67 & 9.09 \\
\hline & & $\begin{array}{l}\text { Very } \\
\text { trustworthy }\end{array}$ & 48.15 & 6.96 & 16.66 & 0 \\
\hline \multirow{5}{*}{$\begin{array}{l}\text { Institutional } \\
\text { trust }\end{array}$} & \multirow{5}{*}{ trust2 } & $\begin{array}{l}\text { Very } \\
\text { distrustful }\end{array}$ & 1.85 & 6.96 & 0 & 9.09 \\
\hline & & $\begin{array}{l}\text { Not too } \\
\text { trustworthy }\end{array}$ & 7.41 & 15.65 & 0 & 52.73 \\
\hline & & $\begin{array}{l}\text { General } \\
\text { trustworthy }\end{array}$ & 9.26 & 38.70 & 50.00 & 21.82 \\
\hline & & $\begin{array}{l}\text { Somewhat } \\
\text { trustworthy }\end{array}$ & 35.19 & 29.13 & 33.33 & 16.36 \\
\hline & & $\begin{array}{l}\text { Very } \\
\text { trustworthy }\end{array}$ & 46.30 & 9.57 & 16.67 & 0 \\
\hline
\end{tabular}




\subsubsection{Control variable}

Referring to similar studies (Hoff and Soares-filho, 2021; Mao et al., 2019; Tama et al., 2021; Zhou et al., 2020), this paper controls other variables that may affect the cleaner production behavior of farmers, including the farmers' basic characteristics, farming characteristics and regional characteristics.

Individual characteristic variables: (1) Age. The older the decision-makers are, the more inclined to adopt the previous experience, and the lower the ability to adopt cleaner production technology. Therefore, the older decision-makers are less likely to adopt cleaner production technology (Bellemare, 2012). (2) The educational level of the decision-makers. Owe to advanced thought and broad horizon, the decision-makers with higher educational levels have stronger ability to accept new knowledge and are more inclined to cleaner production (Key, 2003).

Family characteristic variables: (1) The family with more assets is wealthier and more capable of cleaner production (Conley et al., 2010). (2) Regional variables. According to the economic development and climate conditions, the survey area is divided into the northern Jiangsu area which is assigned a value of 1 and the non-northern Jiangsu area which is assigned a value of 0 .

Farming characteristics: (1) Farming experience. The farming experience is expressed by the breeding experience of broilers. Farmers with longer breeding experience are more experienced and more likely to be subject to traditional thinking habits. They are used to using the previous breeding mode and less possible to use cleaner production technology (Mao et al., 2019). (2) The scale of broiler farming. For the sake of scale efficiency, the farmer who has larger scale of broiler breeding are more willing to improve the breeding environment through cleaner production (Bojnec and Latruffe, 2013). (3) Breeding technology exchange. Technology exchange can improve farmers' understanding of technology and promote farmers' cleaner production behaviors (Krishnan et al., 2014).

Preference characteristics: (1) Risk preference. Farmers who have a higher degree of risk avoidance are often hesitant to try new things and dare not accept them rashly. In order to avoid the risk of capital investment, they often use previous experience and are less willing to cleaner production. Based on Tanaka et al. (2010) and Liu (2013), the study uses experimental economics methods to measure farmers' risk preferences. Furthermore, by considering expected utility theory and prospect theory, we design experiments to measures farmers' risk aversion. 1- $\sigma$ is used to describe the curvature of the value function. It can also be used to describe the degree of risk aversion. The larger value of $\sigma$ indicates that farmers have a higher degree of risk aversion and are less willing to take risks and adopt cleaner production technology. (2) Time preference. Farmers show heterogeneity not only in risk preferences but also in time preferences. Based on the time preference experiments of Tanaka et al. (2010) and Duflo et al. (2011), we calculate the discount rate factor of farmers. The farmers are classified into "short-sighted" farmers and "far-sighted" farmers according to the time preference heterogeneity. Far-sighted farmers have a higher degree of patience, which is more conducive to farmers' cleaner production behavior. The descriptive statistics of variables are shown in Table 3.

Table 3 Variable definitions and descriptive statistics 


\section{Explained variable}

$\begin{array}{lll}\text { Cleaner production } & \begin{array}{l}\text { Equal to } 1 \text { if the farmer had adopted the cleaner } \\ \text { production; otherwise, equal to 0 }\end{array} & 0.1740 .380\end{array}$

\section{Key explanatory variable}

\begin{tabular}{|c|c|c|c|}
\hline $\begin{array}{l}\text { Contract adoption } \\
\text { dummy }\end{array}$ & $\begin{array}{l}\text { Equal to } 1 \text { if the farmer had participated in the contract, } \\
\text { otherwise, equal to } 0 \text {. }\end{array}$ & 0.823 & 0.382 \\
\hline Interpersonal trust & Degree of trust in relatives and friends & 2.991 & 1.165 \\
\hline Institutional trust & Degree of trust in government & 3.164 & 1.006 \\
\hline $\begin{array}{l}\text { Long-term contract } \\
\text { adoption dummy }\end{array}$ & $\begin{array}{l}\text { Equal to } 1 \text { if the farmer had participated in a contract for } \\
1 \text { year or more; otherwise, equal to } 0 \text {. }\end{array}$ & 0.313 & 0.464 \\
\hline
\end{tabular}

\section{Control variable}

\begin{tabular}{|c|c|c|c|}
\hline Age & Actual age of household head in 2015 & 49.342 & 9.578 \\
\hline Education & Years of formal education of the household head & 7.238 & 2.797 \\
\hline Experience & Number of broiler breeding experience (year) & 6.859 & 4.509 \\
\hline Scale & Number of broiler breeding scale (ten thousand) & 4.605 & 4.048 \\
\hline \multirow[t]{3}{*}{ Family assets } & Number of family cars & 0.414 & 0.609 \\
\hline & Number of air conditioners & 1.725 & 1.199 \\
\hline & House area $\left(100 \mathrm{~m}^{2}\right)$ & 2.429 & 1.517 \\
\hline \multirow[t]{5}{*}{ Technology exchange } & $\begin{array}{l}\text { Equal to } 1 \text { if the farmer had no exchange with other } \\
\text { farmers; }\end{array}$ & 4.043 & 0.944 \\
\hline & $\begin{array}{l}\text { Equal to } 2 \text { if the farmer had very little exchange with other } \\
\text { farmers; }\end{array}$ & & \\
\hline & $\begin{array}{l}\text { Equal to } 3 \text { if the farmer had general exchange with other } \\
\text { farmers; }\end{array}$ & & \\
\hline & $\begin{array}{l}\text { Equal to } 4 \text { if the farmer had much more exchange with } \\
\text { other farmers; }\end{array}$ & & \\
\hline & $\begin{array}{l}\text { Equal to } 5 \text { if the farmer had a lot of exchange with other } \\
\text { farmers }\end{array}$ & & \\
\hline Region & $\begin{array}{l}\text { Equal to } 1 \text { northern Jiangsu area; equal to } 0 \text { non-northern } \\
\text { Jiangsu area }\end{array}$ & 0.446 & 0.498 \\
\hline \multicolumn{4}{|l|}{ Instrument variable } \\
\hline Distance & Distance to the nearest breeding enterprise $(\mathrm{km})$ & 20.020 & 11.531 \\
\hline
\end{tabular}


Table 4 shows the basic situation of the surveyed farmers. The data shows that the majority of the sample farmers are between 41 and 55 years old, which indicates that the age of the decision-maker is not very old. The years of education are mostly 8 years or less, which indicates that the overall education level of the farmers is not high. And most of the farming experience are 8 years or less, which shows that farmers have less experience in breeding.

Table 4 Variable definitions and descriptive statistics

\begin{tabular}{|llll|}
\hline item & Proportion (\%) & item & Proportion (\%) \\
\hline Age & & Years of formal education & \\
\hline Under 40 & 18 & 5 years and below & 54 \\
\hline 41 to 55 years old & 56 & 6 to 8 years (including 8 years) & 18 \\
\hline 56 to 65 years old & 22 & 9 to 11 years (including 11 years) & 1 \\
\hline 66 years old and above & 4 & More than 12 years & \\
\hline Region & & Breeding experience & 45 \\
\hline South Jiangsu & 44 & 5 years and below & 23 \\
\hline Central Jiangsu & 19 & 6 to 8 years (including 8 years) & 18 \\
\hline South Jiangsu & 37 & 9 to 11 years (including 11 years) & 14 \\
\hline
\end{tabular}

Table 5 shows the cleaner production behavior of the surveyed farmers. The data shows that among the 345 broiler farms, there are 21 farmers with special sewage treatment equipment or devices[3], accounting for $6.09 \%$. The waste (veterinary drug vaccine packaging) is selected for sale and reuse can be considered as cleaner production. There are 36 farmers who choose to sell or reuse, accounting for $10.43 \%$; and 309 farmers who choose to discard or incinerate, accounting for $89.57 \%$. Saling and reusing the waste (feed-bag) can be considered as cleaner production. Among them, 250 farmers choose to sell, accounting for $72.46 \%$; 13 farmers choose to discard, accounting for 3.77\%; 20 farmers choose to incinerate, accounting for 5.80\%; 62 farmers choose other methods such as recycling, accounting for $17.97 \%$. For the treatment of sick and dead chickens, the way to bury deeply can be considered as cleaner production. Among them, 105 farmers choose to sell, accounting for $30.43 \%$; 152 farmers choose to bury deeply, accounting for $44.06 \%$; 3 farmers choose septic tank compost, accounting for $0.87 \%$; 85 farmers choose to incinerate, accounting for $24.64 \%$. The choice of processing organic fertilizer as the method of excrement treatment can be regarded as cleaner production. Among them, there is 1 farmer who chooses to discard, accounting for $0.29 \%$; 14 farmers who choose to return directly to the field, accounting for $4.06 \%$; 5 farmers choose septic tank compost, accounting for $1.45 \%$; 325 farmers choose to process organic fertilizer, accounting for $94.29 \%$.

Table 5 The basic situation of farmers' cleaner production behaviors 


\begin{tabular}{|llll|}
\hline Project & $\begin{array}{l}\text { Proportion } \\
(\%)\end{array}$ & Project & Proportion(\%) \\
\hline Sewage treatment equipment & & $\begin{array}{l}\text { Treatment of sick and dead } \\
\text { chickens }\end{array}$ & \\
\hline Yes & 6.09 & Sell & 30.43 \\
\hline No & 93.91 & Deeply bury & 44.06 \\
\hline $\begin{array}{l}\text { Treatment of veterinary drug vaccine } \\
\text { packaging }\end{array}$ & & Septic tank compost & \\
\hline Sell or reuse & 10.43 & Incinerate & 0.87 \\
\hline Discard or incinerate & 89.57 & & 24.64 \\
\hline Feed bag treatment & & Feces treatment method & \\
\hline Sell & 72.46 & Unprocessed & 4.35 \\
\hline Discard & 3.77 & Septic tank compost & 1.45 \\
\hline Incinerate & 5.80 & Process organic fertilizer & 94.20 \\
\hline recycle & 17.97 & & \\
\hline
\end{tabular}

[1] The interviews lasted 1 hour per farmer. The total of the farmer's lost work subsidy and the bonus of the lottery game are equivalent to the local 0.5 -day working income. The number of subsidies in this paper is reasonable and has a certain incentive nature.

[2] Cleaner production behavior: The four types of cleaner production activities of farmers are as follows: whether to have special sewage treatment equipment or devices, waste bags (feed, veterinary drugs, vaccines packing materials), dead chicken and waste handling, the four types of waste disposal. By k-means clustering analysis, farmers can be divided into 2 groups, the cleaner production and the non-cleaner production.

[3] There are special sewage treatment equipment or devices can be regarded as cleaner production

\section{Empirical Analysis}

\subsection{Contract farming and cleaner production behavior}

The regression results reporting of the impact of $\mathrm{CF}$ on the cleaner production behavior of farmers are shown in Table 6. From the regression results, the model fits well. Under the control of other influencing factors, contract participation has a significant positive impact on farmers' cleaner production behavior, indicating that farmers who participate in $\mathrm{CF}$ are more inclined to cleaner production. There are three reasons for the result. First of all, CF imposes higher requirements on farmers in terms of cleaner production technology standards. During the production process, farmers will be provided with a credit service for the means of production, which can therefore exclude at the source the means of production that harm the ecological environment. In terms of production, CF can (1) provide farmers with technical support and guidance services throughout the 
production process, (2) promote and demonstrate cleaner production for farmers, and (3) provide strong support for farmers to use cleaner production technology. 
Table 6

OLS estimation results of the impact of CF and farmers' cleaner production behavior

\begin{tabular}{|c|c|c|c|c|c|c|}
\hline & \multicolumn{3}{|c|}{$\begin{array}{l}\text { Whether or not adopts cleaner } \\
\text { production }\end{array}$} & \multicolumn{3}{|c|}{$\begin{array}{l}\text { Whether or not adopts cleaner } \\
\text { production }\end{array}$} \\
\hline & (1) & (2) & (3) & (4) & (5) & (6) \\
\hline \multirow[t]{2}{*}{ Contract farming } & $0.092^{\star *}$ & $0.094^{\star}$ & $0.095^{\star}$ & -- & -- & -- \\
\hline & $(0.045)$ & $(0.050)$ & $(0.050)$ & -- & -- & -- \\
\hline \multirow{2}{*}{$\begin{array}{l}\text { Long-term } \\
\text { contract }\end{array}$} & -- & -- & -- & $0.097 * \star$ & 0.110 ** & $0.110^{* *}$ \\
\hline & -- & -- & -- & $(0.047)$ & $(0.047)$ & $(0.050)$ \\
\hline \multirow[t]{2}{*}{ Experience } & -- & 0.003 & 0.005 & -- & 0.008 & 0.009 \\
\hline & -- & $(0.042)$ & $(0.042)$ & -- & $(0.042)$ & $(0.042)$ \\
\hline \multirow[t]{2}{*}{ Scale } & -- & 0.006 & 0.006 & -- & 0.004 & 0.004 \\
\hline & -- & $(0.006)$ & $(0.006)$ & -- & $(0.005)$ & $(0.005)$ \\
\hline \multirow[t]{2}{*}{ Family assets 1} & -- & $0.029 *$ & $0.030 *$ & -- & $0.027^{\star}$ & $0.027^{\star}$ \\
\hline & -- & $(0.015)$ & $(0.015)$ & -- & $(0.015)$ & $(0.015)$ \\
\hline \multirow[t]{2}{*}{ Family assets 2} & -- & $0.034^{\star}$ & $0.034^{\star}$ & -- & $0.042^{\star \star}$ & $0.042^{\star \star}$ \\
\hline & -- & $(0.020)$ & $(0.020)$ & -- & $(0.020)$ & $(0.020)$ \\
\hline \multirow[t]{2}{*}{ Risk preference } & -- & 0.030 & 0.029 & -- & 0.005 & 0.005 \\
\hline & -- & $(0.077)$ & $(0.077)$ & -- & $(0.077)$ & $(0.077)$ \\
\hline \multirow[t]{2}{*}{ Training } & -- & $0.091^{\star *}$ & $0.089 *$ & -- & $0.101^{\star \star}$ & $0.100 * \star$ \\
\hline & -- & $(0.045)$ & $(0.048)$ & -- & $(0.045)$ & $(0.047)$ \\
\hline \multirow[t]{2}{*}{ Age } & -- & -- & -0.001 & -- & -- & -0.000 \\
\hline & -- & -- & $(0.002)$ & -- & -- & $(0.002)$ \\
\hline \multirow[t]{2}{*}{ Education } & -- & -- & 0.000 & -- & -- & 0.000 \\
\hline & -- & -- & $(0.008)$ & -- & -- & $(0.008)$ \\
\hline \multirow[t]{2}{*}{ Constant } & $0.098^{\star *}$ & $-0.156^{*}$ & -0.090 & $0.143^{* \star *}$ & -0.107 & -0.103 \\
\hline & $(0.038)$ & $(0.085)$ & $(0.144)$ & $(0.023)$ & $(0.077)$ & $(0.157)$ \\
\hline Observations & 345 & 345 & 345 & 345 & 345 & 345 \\
\hline$r^{2}$ & 0.009 & 0.048 & 0.049 & 0.014 & 0.057 & 0.057 \\
\hline
\end{tabular}


Secondly, the leading enterprises in CF are strong economically. The contracted enterprises possess advantages in terms of credit and social resources, and they can use their relationships with the banking sector to support farmers in developing cleaner production and provide preferential loan policies and relevant financial support to contract farmers carrying out cleaner production.

Third, CF provides farmers with a full range of agricultural product circulation services, such as providing farmers with special agricultural products trading venues, helping contract farmers complete agricultural product processing and transportation, and creating brands, which is more conducive to farmers' participation in cleaner production. For the sake of reputation, enterprises will impose certain requirements on product quality and environmental impacts, thereby promoting cleaner production by farmers.

Finally, as far as developing countries are concerned, farming exhibits several traits that differentiate it from the more industrialized farming practiced in developed countries: (1) farming operations tend to be smallscale, (2) farmers generally have low levels of education, (3) production and management techniques are poor, and (4) infrastructure such as transportation, cold storage, and information channels are underdeveloped. Signing contracts with agricultural enterprises is an effective way for farmers to enable their products to enter high-end markets and obtain higher returns. Farmers will be more inclined to adopt cleaner production technology in order to obtain such higher returns and meet the requirements of high-end markets.

Using Guangdong Wen's Food Group Co., Ltd. (hereinafter referred to as Wen's) as an example, Wen's adopted the cooperation model of production contracts to sign contracts with farmers and promote the application of degradable bed technology outside the house via various subsidiaries' regional management companies. A degradable bed has characteristics such as fully degradable feces, low labor intensity, small land occupation, and low construction cost. In schedule management, Wen's instruct contracted farmers to carry out daily operations in accordance with the degradable bed operation and management operation specifications. It also required farmers to keep relevant records in an environmental protection operation record book to further promote the cleaner production of contracted farmers. In practice, this has meant that whereas most uncontracted farmers do not clean their waste, farmers who contract with Wen's usually do. Therefore, participating in CF can promote farmers' cleaner production technology adoption.

\subsection{Social trust and cleaner production behavior}

The regression results of the impact of interpersonal trust and institutional trust on farmers' cleaner production behavior are shown in Table 6, which reports the regression results of the instrumental variables used to measure farmers' cleaner production behavior. In Table 7, the regression results all show that trust has a positive effect on farmers' cleaner production behavior. From the perspective of different dimensions of trust, both interpersonal and institutional trust show a statistically significant impact on farmer cleaner production technology adoption; specifically, both interpersonal and institutional trust have a positive effect on farmers' cleaner production behavior. 
Table 7

OLS estimation results of the impact of social trust and farmers' cleaner production behaviors

\section{Cleaner production}

\begin{tabular}{|c|c|c|c|c|c|c|c|}
\hline & (1) & (2) & (3) & (4) & (5) & (6) & (7) \\
\hline \multirow[t]{2}{*}{ Institutional Trust } & -- & -- & -- & $0.197 \star \star \star$ & $0.194^{\star \star \star}$ & $0.194^{\star \star \star}$ & $0.142^{\star \star \star}$ \\
\hline & -- & -- & -- & $(0.019)$ & $(0.019)$ & $(0.020)$ & $(0.018)$ \\
\hline \multirow[t]{2}{*}{ Interpersonal trust } & $0.168^{\star \star \star}$ & $0.168 * \star \star$ & 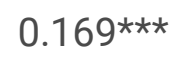 & -- & -- & -- & $0.124 * \star \star$ \\
\hline & $(0.017)$ & $(0.017)$ & $(0.017)$ & -- & -- & -- & $(0.016)$ \\
\hline \multirow[t]{2}{*}{ Experience } & -- & 0.001 & 0.007 & -- & -0.051 & -0.049 & -0.032 \\
\hline & -- & $(0.036)$ & $(0.037)$ & -- & $(0.036)$ & $(0.036)$ & $(0.033)$ \\
\hline \multirow[t]{2}{*}{ Scale } & -- & 0.001 & 0.000 & -- & 0.001 & 0.000 & -0.002 \\
\hline & -- & $(0.005)$ & $(0.005)$ & -- & $(0.004)$ & $(0.004)$ & $(0.004)$ \\
\hline \multirow[t]{2}{*}{ Family assets 1} & -- & $0.027 \star \star$ & $0.027 \star \star$ & -- & 0.017 & 0.018 & $0.020 *$ \\
\hline & -- & $(0.012)$ & $(0.012)$ & -- & $(0.013)$ & $(0.014)$ & $(0.012)$ \\
\hline \multirow[t]{2}{*}{ Family assets 2} & -- & $0.032^{*}$ & $0.033^{*}$ & -- & 0.019 & 0.019 & 0.022 \\
\hline & -- & $(0.018)$ & $(0.018)$ & -- & $(0.017)$ & $(0.017)$ & $(0.016)$ \\
\hline \multirow[t]{2}{*}{ Risk preference } & -- & 0.049 & 0.048 & -- & 0.023 & 0.022 & 0.041 \\
\hline & -- & $(0.065)$ & $(0.065)$ & -- & $(0.064)$ & $(0.064)$ & $(0.058)$ \\
\hline \multirow[t]{2}{*}{ Training } & -- & 0.010 & -0.001 & -- & 0.090 ** & $0.089 * *$ & 0.016 \\
\hline & -- & $(0.043)$ & $(0.045)$ & -- & $(0.040)$ & $(0.042)$ & $(0.043)$ \\
\hline \multirow[t]{2}{*}{ Age } & -- & -- & -0.000 & -- & -- & -0.001 & -0.001 \\
\hline & -- & -- & $(0.002)$ & -- & -- & $(0.002)$ & $(0.002)$ \\
\hline \multirow[t]{2}{*}{ Education } & -- & -- & 0.007 & -- & -- & -0.001 & 0.005 \\
\hline & -- & -- & $(0.008)$ & -- & -- & $(0.007)$ & $(0.007)$ \\
\hline \multirow[t]{2}{*}{ Constant } & $-0.329 \star \star \star *$ & 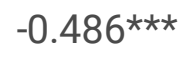 & $-0.533^{\star \star \star}$ & 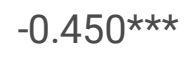 & $-0.578^{\star \star \star}$ & $-0.505^{\star \star \star}$ & $-0.752^{\star \star \star}$ \\
\hline & $(0.045)$ & $(0.076)$ & $(0.142)$ & $(0.052)$ & $(0.081)$ & $(0.132)$ & $(0.130)$ \\
\hline Observations & 345 & 345 & 345 & 345 & 345 & 345 & 345 \\
\hline$r^{2}$ & 0.266 & 0.292 & 0.295 & 0.273 & 0.292 & 0.293 & 0.412 \\
\hline
\end{tabular}

Note: $* \star \star, * *, *$ indicates that the estimated result is significant at the level of $1 \%, 5 \%, 10 \%$ and the numbers in parentheses are standard errors

Specifically, interpersonal trust (trust1) shows statistical significance at the $5 \%$ confidence level. That is to say, with other conditions unchanged, the more farmers trust their relatives and friends, the greater the probability 
that they will adopt cleaner production technology. The possible reason for this behavior is that under the conditions of the contract responsibility system, farmers maintain relationships with relatives and friends through long-term "investments" and by "visiting relatives and friends," which serve as important bonds for mutual cooperation between farmers. Close communication between relatives and friends promotes information sharing, reduces the cost of information searches for partners, and promotes cooperation contracts between farmers. The cleaner production behavior of farmers includes waste resource utilization and waste treatment, among others, and forms a complex systematic project that requires collection, sorting, storage, and processing. The support of relatives and friends provides a "trust guarantee" mechanism that can help ensure that farmers do not engage in opportunistic behavior.

In addition, relationships in rural neighborhood mainly center on "acquaintance society." This is the orientation of traditional Chinese social relations, and it is also a manifestation of human relations and culture in geographic relations. Neighborhood relationships feature long-term and high-frequency interactions where "common courtesy goes a long way" relationships prevail. Neighbor interactions can not only reduce the transaction costs of neighborhood cooperation, but also enhance mutual identity. The trust and reputation generated through long-term communication between relatives and friends gradually becomes institutionalized, whereby participants' words and deeds will converge to adhering to unspoken common principles. The more trust farmers have in relatives and friends, the higher their expectations will be for future cooperation, which promotes the formation of a reciprocal mechanism that shares risks and benefits.

Good evaluations brought about by observing relatives' and friends' cleaner production behavior will have a spurring effect that can be spread through interaction between farmers. In rural "acquaintance society" communities, farmers will consciously maintain social relations with relatives and friends and will thus consciously abide by social norms-including cleaner production.

Institutional trust (trust2) was found to be statistically significant at a confidence level of $1 \%$. That is to say, keeping other conditions unchanged, the more trust farmers have in the government, the greater the probability that they adopt cleaner production technology. The possible reason for this finding is that higher trust in the government carries over into higher trust in government departments. This increases the ability of government departments to form an informal system in rural areas that can reduce uncertainty and various risks. It also enhances farmers' confidence in these departments as a source for obtaining technical guidance and policy support. Combined, these effects promote cleaner production by farmers.

In addition, farmer cleaner production as a model of waste resource utilization based on a certain economic basis, must adhere to policies and regulations promulgated by government departments. The higher a farmer's trust in government departments, the more willing the farmer will be to obey such oversight and regulations. For example, government departments have issued "Agricultural Waste Disposal and Utilization Measures" and other regulations to restrict farmers' behavior. But due to farmers' awareness and the mentality of "the law cannot be everywhere at once," the expected policy goals have not been achieved. This shows that trust in government departments can help improve farmers' cleaner production behavior.

\subsection{Mechanism analysis}


Participating in CF can directly affect farmers' cleaner production behavior through both incentive mechanisms and constraints (such as cleaner production subsidies, among others), as well as indirectly by helping farmers improve interpersonal and institutional trust. This part focuses on testing whether participation in CF affects farmers' cleaner production behaviors by increasing farmers' interpersonal trust and institutional trust. The regression results are shown in Tables 8 and 9. Column (1) presents the regression result of the impact of participating in $\mathrm{CF}$ on cleaner production behavior, and the conclusion is the same as in the benchmark. Column (2) shows the regression result of the impact of social trust on cleaner production behavior. The higher a farmer's degree of interpersonal and institutional trust, the higher the probability of cleaner production. 
Table 8

OLS estimated results of contract farming, trust and farmers' cleaner production behaviors

\section{Mechanism Analysis}

(1)

Cleaner production

$\begin{array}{ll}\text { Contract farming } & 0.095^{*} \\ & (0.050)\end{array}$

Interpersonal trust $\quad--$

$--$

Age

Eduction

Experience

Scale

$-0.001$

(0.002)

0.000

(0.008)

0.005

$(0.042)$

0.006

(0.006)

Family assets 1

0.030 *

(0.015)

Family assets 2

$0.034^{*}$

$(0.020)$

Risk preference

0.029

(0.077)

$0.089 *$

(0.048)

$-0.090$

(0.144)

Observations

$r^{2}$

345

0.049
(2)

(3)

(4)

Cleaner production

$--$

--

0.169 ***

(0.017)

$-0.000$

(0.002)

0.007

(0.008)

0.007

(0.037)

0.000

(0.005)

$0.027^{\star *}$

(0.012)

$0.033^{*}$

(0.018)

0.048

(0.065)

$-0.001$

(0.045)

$-0.533^{\star \star \star}$

(0.142)

345

0.295

Note: $* \star \star, \star \star *$, indicates that the estimated result is significant at the level of $1 \%, 5 \%, 10 \%$ and the numbers in parentheses are standard errors 
Table 9

OLS estimated results of contract farming, trust and farmers' cleaner production behavior

\section{Mechanism Analysis}

(1)

Cleaner production

Contract farming $\quad$ 0.095*

$(0.050)$

Social Trust

$--$

$-0.001$

$(0.002)$

0.000

(0.008)

Experience

0.005

$(0.042)$

0.006

(0.006)

Family assets $1 \quad 0.030^{*}$

(0.015)

Family assets $2 \quad 0.034$ *

$(0.020)$

Risk preference $\quad 0.029$

$(0.077)$

$0.089 *$

$(0.048)$

$-0.090$

(0.144)

Observations

345

$r^{2}$

0.049
$--$
(2)

(3)

(4)

Cleaner production Interpersonal trust Cleaner production

$-$

$--$

$0.194^{\star \star \star}$

$(0.020)$

$-0.001$

(0.002)

$-0.001$

(0.007)

$-0.049$

(0.036)

0.000

(0.004)

0.018

(0.014)

0.019

(0.017)

0.022

(0.064)

0.089 **

(0.042)

$-0.505^{\star \star \star}$

(0.132)

345

0.293 $0.471^{\star \star \star}$

(0.139)

$-$

--

0.000

(0.006)

0.004

(0.020)

$0.281^{\star \star \star}$

(0.108)

0.029 **

(0.013)

$0.063^{*}$

(0.035)

0.076 *

(0.042)

0.033

(0.195)

0.004

(0.134)

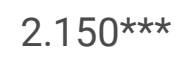

(0.423)

345

0.078
0.004

(0.044)

0.194 **

(0.020)

$-0.001$

(0.002)

$-0.001$

(0.007)

$-0.049$

(0.036)

0.000

(0.004)

0.018

(0.014)

0.019

(0.017)

0.022

(0.064)

0.089 **

$(0.043)$
Note: $\star \star \star, * \star, *$ indicates that the estimated result is significant at the level of $1 \%, 5 \%, 10 \%$ and the numbers in parentheses are standard errors 
Column (3) provides the regression result of the impact of CF on social trust. It can be seen that participating in CF has a significantly positive impact on farmers' trust. The reason is that in busy farming season, farmers will generally suffer from a seriously insufficient labor force, and members within the contract organization will help each other, which is a kind of job changing behavior. Such labor exchange behavior is a kind of human resources coordination and mutual aid relationship, which can increase the mutual benefits of social exchanges between farmers and is conducive to the establishment of a stable social network. For example, in the broiler breeding industry, during busy times such as chicken catching and vaccinations, there will be a serious shortage of labor in farmer families, and members within the contract organization respond by taking turns to help each other.

Column (4) includes both CF and social trust. In this column, the coefficient of trust is still significantly positive, whereas the coefficient of CF is still positive but not statistically significant. Thus, CF can be seen as an intermediary variable that can influence the cleaner production behavior of farmers by influencing their social trust.

\subsection{Robustness test}

\subsubsection{Endogenous problem control}

In view of the endogenous nature of contract participation, this research first uses the instrumental variable method and endogenous transformation model to analyze contract farming and farmers' cleaner production behavior. The method of Key (2013) was used to select the distance between farmers and the nearest breeding company (selected companies have all operated locally for a certain period of time, and recently established breeding companies are not included) as an instrumental variable. This choice reflects the possibility that farmers will come into contact with breeding enterprises in production. The regression results are shown in Table 10. The closer farmers are to the nearest breeding enterprises, the lower their transaction costs (for example, the convenience of technical service and selling broilers), and the more inclined they are to participate in CF. 
Table 10

Estimated results of the IV and endogenous transformation model for contractual agriculture and farmers' cleaner production behaviors

\begin{tabular}{|c|c|c|c|c|c|c|}
\hline & \multicolumn{3}{|l|}{ IV } & \multicolumn{3}{|c|}{ Endogenous transformation model } \\
\hline & \multirow{2}{*}{$\begin{array}{l}\text { Contract } \\
\text { participation } \\
\text { (1) }\end{array}$} & \multicolumn{2}{|c|}{ Cleaner production } & \multirow{2}{*}{$\begin{array}{l}\text { Contract } \\
\text { participation } \\
(4)\end{array}$} & \multicolumn{2}{|c|}{ Cleaner production } \\
\hline & & (2) & (3) & & (5) & (6) \\
\hline \multirow{2}{*}{$\begin{array}{l}\text { Contract } \\
\text { farming }\end{array}$} & -- & $0.157^{\star *}$ & $0.162^{\star \star}$ & -- & $0.622^{\star}$ & $0.618^{*}$ \\
\hline & -- & $(0.079)$ & $(0.081)$ & -- & $(0.370)$ & $(0.370)$ \\
\hline \multirow[t]{2}{*}{ Experience } & -0.007 & 0.005 & 0.007 & 0.044 & 0.013 & 0.028 \\
\hline & $(0.032)$ & $(0.042)$ & $(0.042)$ & $(0.227)$ & $(0.169)$ & $(0.172)$ \\
\hline \multirow[t]{2}{*}{ Scale } & -0.002 & 0.007 & 0.006 & -0.018 & 0.024 & 0.023 \\
\hline & $(0.004)$ & $(0.006)$ & $(0.006)$ & $(0.022)$ & $(0.018)$ & $(0.018)$ \\
\hline \multirow[t]{2}{*}{ Family assets 1} & -0.020 & $0.031^{\star *}$ & $0.032^{\star \star}$ & $-0.137 \star \star$ & $0.121^{\star \star}$ & $0.124^{\star \star}$ \\
\hline & $(0.013)$ & $(0.015)$ & $(0.015)$ & $(0.065)$ & $(0.054)$ & $(0.054)$ \\
\hline \multirow[t]{2}{*}{ Family assets 2} & 0.007 & $0.033^{*}$ & $0.033^{*}$ & -0.015 & $0.113^{\star}$ & $0.116^{*}$ \\
\hline & $(0.013)$ & $(0.020)$ & $(0.019)$ & $(0.087)$ & $(0.064)$ & $(0.064)$ \\
\hline \multirow[t]{2}{*}{ Risk preference } & $-0.165^{\star \star \star}$ & 0.035 & 0.034 & $-1.129 * \star \star$ & 0.173 & 0.167 \\
\hline & $(0.070)$ & $(0.076)$ & $(0.076)$ & $(0.385)$ & $(0.304)$ & $(0.304)$ \\
\hline \multirow[t]{2}{*}{ Training } & $1.141^{\star \star \star}$ & $0.081^{*}$ & 0.078 & $0.693^{\star \star \star}$ & 0.444 & 0.430 \\
\hline & $(0.055)$ & $(0.046)$ & $(0.049)$ & $(0.253)$ & $(0.274)$ & $(0.276)$ \\
\hline \multirow[t]{2}{*}{ Age } & -0.001 & -- & -0.001 & -0.004 & -- & -0.005 \\
\hline & $(0.002)$ & -- & $(0.002)$ & $(0.012)$ & -- & $(0.009)$ \\
\hline \multirow[t]{2}{*}{ Education } & -0.004 & -- & 0.000 & -0.033 & -- & 0.008 \\
\hline & $(0.006)$ & -- & $(0.008)$ & $(0.040)$ & -- & $(0.031)$ \\
\hline \multirow[t]{2}{*}{ Distance } & $-0.019 * \star *$ & -- & -- & $-0.093^{\star \star \star}$ & -- & -- \\
\hline & $(0.001)$ & -- & -- & $(0.010)$ & -- & -- \\
\hline \multirow[t]{2}{*}{ Constant } & $1.360 * \star \star$ & $-0.207 * \star$ & -0.139 & $4.043^{\star \star \star}$ & $-2.572^{\star \star \star}$ & $-2.369 * \star \star$ \\
\hline & $(0.140)$ & $(0.097)$ & $(0.140)$ & $(0.893)$ & $(0.488)$ & $(0.726)$ \\
\hline Observations & 345 & 345 & 345 & 345 & 345 & 345 \\
\hline
\end{tabular}

Note: $* \star \star, * *, *$ indicates that the estimated result is significant at the level of $1 \%, 5 \%, 10 \%$ and the numbers in parentheses are standard errors 


\begin{tabular}{|c|c|c|c|c|c|c|}
\hline \multicolumn{4}{|c|}{ IV } & \multicolumn{3}{|c|}{ Endogenous transformation model } \\
\hline $\begin{array}{l}\text { F value/Wald } \\
\text { value }\end{array}$ & $16.56^{\star \star \star}$ & $18.77^{\star \star \star}$ & $16.56^{\star \star \star}$ & - & $98.86^{\star \star \star}$ & $99.52^{\star \star \star}$ \\
\hline
\end{tabular}

However, this variable does not have a direct impact on farmers' cleaner production behavior. Nonetheless, the result supports the finding that participation in $\mathrm{CF}$ can improve the level of cleaner production. In addition, the distance to the nearest broiler breeding company has a significantly negative impact on the contractual participation of farmers, whereby that the farther the distance from the nearest broiler breeding company, the lower the probability of a farmer participating in CF. The reason is that the farther the distance from a chicken farm to the enterprise, the higher the farmer's transaction costs (to receive feed, baby chicks, and veterinary drugs, and freight for selling broiler chickens, among others), which further proves that transaction costs are an important factor affecting farmers' participation in CF.

\subsubsection{Other robustness tests}

In addition, this paper uses whether farmers participate in long-term contracts as a robustness test of CF's effect on farmers' cleaner production behavior. The result shows that after controlling for other influencing factors, participating in a long-term contract has a significantly positive impact on farmers' cleaner production behavior. This indicates that farmers who participate in a long-term contract are more inclined to engage in cleaner production, for the following reasons. First, the contract system regulates the conduct of different participants through the provisions stipulated in the signed contracts. The contract will include the quantity and date of delivery. Once the farmer signs a long-term contract with an enterprise, the longer the farmer has been engaged in production in the industry, the more incentives the farmer will have to engage in cleaner production. Additionally, in order to save transaction costs, companies are more willing to provide technical training and technical guidance to farmers who sign a long-term contract and will promote cleaner production by such long-term contract farmers. In addition, cleaner production often functions as a special asset, with specific functions. In order to guarantee the stability of contracts and improve their reputation, leading enterprises usually use rules and regulations, such as institutional constraints, to restrict long-term contracted farmers to increase such special investment.

\section{Discussion And Conclusions}

In 2016, the Chinese government put forward its Plan for Promoting the Pilot Program for the Utilization of Agricultural Wastes, which clearly states that cleaner production by farmers is an important part of rural environmental governance. Cleaner production is a positive measure that can solve problems with the unclean and polluted state of the rural environment and can respond to the new normal of the economy. Different from existing research from the perspective of farmer characteristics, this paper takes the perspective of micro farmer contracts and trust, based on survey data of 345 broiler farmers in 11 regions (cities) in Jiangsu Province. Using instrumental variable methods and endogenous conversion models, this paper focuses on farmers' motivation for adopting cleaner production technology under the constraints of social environment (such as interpersonal trust, institutional trust, and CF). 
The main research conclusions are as follows. First, CF has a significant role in promoting farmers' cleaner production behavior. Compared with non-contract farmers, farmers who participate in a contract have a higher probability of adopting cleaner production technology. Second, CF has a significant positive impact on the interpersonal and institutional trust of farmers. Compared with non-contract farmers, contract farmers have a higher degree of trust in relatives, friends, and government departments. Third, interpersonal and institutional trust have a significant positive impact on farmers' cleaner production behaviors. The higher a farmer's degree of trust in relatives, friends, and government departments, the higher the farmer's probability of adopting cleaner production technology. In addition, CF can indirectly improve the cleaner production of farmers by increasing their institutional and interpersonal trust.

Based on the above research results, this article identifies the following policy implications and offers the following policy suggestions. First, in real society, interpersonal and institutional trust are not inherent in nature, but are the result of the active construction of social networks by socially embedded individuals. The process of building trust is also a process of mutual development, support, and understanding, as well as acceptance of others. Therefore, the government should use various forms and types of media to create a social norm of mutual benefit and mutual trust for farmers. This could strengthen farmers' guilt fat using uncleaner production while enhancing the pride and intention of farmers to engage in cleaner production.

Secondly, under the incentive effect of such "promotion championship," it is easy for government departments to ignore environmental governance. However, people's dissatisfaction with the urban and rural environment is increasing day by day, so government departments should pay attention to environmental governance as a performance evaluation system and consider the improvement of the rural environment as an important governmental goal. In addition, the environmental governance of rural areas should be resolved through environmental protection laws and regulations. Such measures to constrain governments, enterprises, and farmers in order to encourage farmers to believe the government's promises regarding environmental governance, thereby increasing farmers' trust in government departments.

Finally, farmers should be guided to participate in CF according to their needs and actual conditions, and cleaner production behavior should be promoted among farmers by improving their organization. The government should create conditions to encourage the development of contracted agriculture and use it as a mechanism to encourage and support farmers in adopting cleaner production technology. The government should also increase its publicity of ecological environmental protection and raise farmers' awareness of environmental protection.

Although some progress has been made, due to the limited time and capacity, there are still many areas to be improved, which will be the direction of future research. First, it has been proved in the technology-intensive aquaculture industry, but its promotion in other industries remains to be verified, and subsequent research should be further expanded. Second, this study only includes the cross-section data of the first phase. In the analysis of farmers' cleaner production behavior, continuous multi-period panel data has a better effect. Therefore, a follow-up survey will be conducted on farmers to evaluate the dynamic change process of their cleaner production technology adoption behavior.

\section{Declarations}

Page 24/30 
Ethical Approval: Not applicable

Consent to Participate: Not applicable

Consent to Publish: Not applicable

Authors Contributions: MH worked out the plot of this research and written. FY reviewed literature and written. CGQ organized data and guided writing. CSJ designed empirical model. All authors read and approved the final manuscript.

Funding: The work was supported by the "National Natural Sciences Foundation (71573130)”, "China Postdoctoral Science Foundation (2020T130393; 2019M653541)", "Shaanxi Federation of Humanities and Social Sciences Circles Research Program (2020Z005; 20FN-49)”.

Competing Interests: The authors declare that they have no competing interests.

Availability of data and materials:

The datasets generated and/or analysed during the current study are not publicly available due we collect the data by field investigation and are not available from the corresponding author on reasonable request.

\section{References}

1. Acemoglu, D., P., Antràs, \& Helpman, E. (2007). Contracts and technology adoption, American Economic Review, 97 (3), 916-943.

2. Alpenberg, J., \& Scarbrough, D., P. (2018). Trust and control in changing production environments. Journal of Business Research, 88, 527-534.

3. Antràs, P. (2005). Incomplete contracts and the product cycle, American Economic Review, 95 (4), $1054-$ 1073.

4. Azadi, Y., Yazdanpanah, M., \& Mahmoudi, H. (2019). Understanding smallholder farmers' adaptation behaviors through climate change beliefs, risk perception, trust, and psychological distance: Evidence from wheat growers in Iran. Journal of Environmental Management, 250, 109456.

5. Bellemare, M., F., \& Bloem, J., R. (2018). Does contract farming improve welfare? A review. World Development, 112, 259-271.

6. Bellemare, M., F. (2012). As you sow, so shall you reap: The welfare impacts of contract farming. World Development, 40(7), 1418-1434.

7. Ben-ner, A., \& Putterman, L. (2009). Trust, communication and contracts: An experiment. Journal of Economic Behavior \& Organization, 55(4), 106-121.

8. Bergh, A., \& Öhrvall, R. (2018). A sticky trait: Social trust among Swedish expatriates in countries with varying institutional quality. Journal of Comparative Economics, 46(4), 1146-1157.

9. Babin, N., Mullendore, N., D., \& Prokopy, L., S. (2016). Using social criteria to select watersheds for nonpoint source agricultural pollution abatement projects. Land Use Policy, 55, 327-333. 
10. Bojnec, Š., \& Latruffe, L. (2013). Farm size, agricultural subsidies and farm performance in Slovenia. Land Use Policy, 32, 207-217.

11. Braganza, A., Chen, W., Canhoto, A., \& Sap, S. (2020). Productive employment and decent work: The impact of Al adoption on psychological contracts, job engagement and employee trust. Journal of Business Research. Forthcoming.

12. Cao, H., Zhu, X., Heijman, W., \& Zhao, K. (2020). The impact of land transfer and farmers' knowledge of farmland protection policy on pro- environmental agricultural practices: the case of straw return to fields in Ningxia, China. Journal of Cleaner Production, Forthcoming.

13. Chadwick, D., Wei, J., Yan, T., Guanghui, Y., Qirong, S., \& Qing, C. (2015). Agriculture, ecosystems and environment improving manure nutrient management towards sustainable agricultural intensification in China. Agriculture, Ecosystems and Environment, 209, 34-46.

14. Chen, S., Han, X., \& Jebran, K. (2020). Journal of contemporary social trust environment and tunneling. Journal of Contemporary Accounting \& Economics, 16(3), 100212.

15. Cobo-reyes, R., Lacomba, J., A., Lagos, F., \& Levin, D. (2017). The effect of production technology on trust and reciprocity in principal-agent relationships with team production. Journal of Economic Behavior \& Organization, 137, 324-338.

16. Conley, T., G., \& Udry, C., R. (2010). Learning about a new technology: Pineapple in Ghana. American Economic Review, 100(1), 35-69.

17. Dang, H., Li, E., \& Nuberg, I. (2014). Farmers' perceived risks of climate change and influencing factors: A study in the Mekong Delta, Vietnam. Environmental Management, 54, 331-345.

18. Duflo, B., E., Kremer, M., \& Robinson, J. (2011). Nudging farmers to use fertilizer: Theory and experimental evidence from Kenya. American Economic Review, 101(6), 2350-2390.

19. Fisher, M., \& Kandiwa, V. (2014). Can agricultural input subsidies reduce the gender gap in modern maize adoption? Evidence from Malawi. Food Policy, 45, 101-111.

20. Foster, A., D., \& Rosenzweig, M., R. (2004). Technological change and the distribution of schooling: Evidence from green-revolution India. Journal of Development Economics, 74(1), 87-111.

21. Fukuyama, F. (1995). Trust: The social virtues and the creation of prosperity, New York: The Free Press.

22. Giannetti, B., F., Agostinho, F., Eras, J., J., C., Yang, Z., \& Almeida, C., M., V., B. (2020). Cleaner production for achieving the sustainable development goals. Journal of Cleaner Production, 271, 122127.

23. Goeb, J., \& Lupi, F. (2021). Showing pesticides' true colors: The effects of a farmer-to-farmer training program on pesticide knowledge. Journal of Environmental Management, 279, 111821.

24. Gramzow, A., Batt, P., J., Afari-sefa, V., Petrick, M., \& Roothaert, R. (2018). Linking smallholder vegetable producers to markets - A comparison of a vegetable producer group and a contract-farming arrangement in the Lushoto District of Tanzania. Journal of Rural Studies, 63, 168-179.

25. Grossman, S., \& Hart, O. (1986). The costs and benefits of ownership, Journal of Political Economy, 94 (4), 691-719.

26. Hartmann, E., \& Herb, S. (2014). Opportunism risk in service triads: A social capital perspective. International Journal of Physical Distribution and Logistics Management, 44(3), 242-256. 
27. He, G., Liu, T., \& Zhou, M. (2020). Straw burning, PM2.5, and death: Evidence from China. Journal of Development Economics, 145, 102468.

28. Herweg, F., Karle, H., \& Müller, D. (2018). Incomplete contracting, renegotiation, and expectation-based loss aversion. Journal of Economic Behavior \& Organization, 145, 176-201.

29. Hoff, R., Van Der, \& Soares-filho, B. (2021). Will farmers seek environmental regularization in the Amazon and how? Insights from the Rural Environmental Registry (CAR) questionnaires. Journal of Environmental Management, 284, 112010.

30. Huang, Z., Xu, Y., Zeng, D., Wang, C., \& Wang, J. (2018). One size fits all? Contract farming among broiler producers in China. Journal of Integrative Agriculture, 17(2), 473-482.

31. Huong, T., L., T., Takahashi, Y., Nomura, H., Truong, C., Kusudo, T., \& Yabe, M. (2020). Science of the Total Environment Manure management and pollution levels of contract and non-contract livestock farming in Vietnam. Science of the Total Environment, 710, 136200.

32. Joffre, O., M., Vries, J., R. De, Klerkx, L., \& Poortvliet, P., M. (2020). Why are cluster farmers adopting more aquaculture technologies and practices? The role of trust and interaction within shrimp farmers' networks in the Mekong Delta, Vietnam. Aquaculture, 523, 735181.

33. Key, N. (2003). Production contracts and productivity in the U.S. Hog Sector. American Journal of Agricultural Economics, 85(1), 121-133.

34. Key, N. (2013). Production contracts and farm business growth and survival. Journal of Agricultural and Applied Economics, 45(2), 277-293.

35. Key, N., \& Runsten, D. (1999). Contract farming, smallholders, and rural development in Latin America: The organization of agroprocessing firms and the scale of outgrower production. World Development, 27(2), 381-401.

36. Khan, M., F., Nakano, Y., \& Kurosaki, T. (2019). Impact of contract farming on land productivity and income of maize and potato growers in Pakistan. Food Policy, 85(4), 28-39.

37. Koutsou, S., Partalidou, M., \& Ragkos, A. (2014). Young farmers' social capital in Greece: Trust levels and collective actions. Journal of Rural Studies, 34, 204-211.

38. Krishnan, P., \& Manasa, P. (2014). Neighbors and extension agents in Ethiopia: Who matters more for technology adoption? American Journal of Agricultural Economics, 1, 308-327.

39. Li, M., Wang, J., Zhao, P., Chen, K., \& Wu, L. (2020). Factors affecting the willingness of agricultural green production from the perspective of farmers' perceptions. Science of the Total Environment, 738(35), 140289.

40. Liu, E., M. (2013). Time to change what to sow: Risk preferences and technology adoption decisions of cotton farmers in China. Review of Economics and Statistics, 95(4), 1386-1403.

41. Luhmann, N. (1979). Trust and power. New York: John Wiley and Sons.

42. Luo, J., \& Wang, X. (2020). Hukou identity and trust-Evidence from a framed field experiment in China. China Economic Review, 59(206), 101383.

43. Mao, H., Zhou, L., Ifft, J., \& Ying, R., Y. (2019). Risk preferences, production contracts and technology adoption by broiler farmers in China. China Economic Review, 54(4), 147-159. 
44. Macleod, M., Moran, D., Eory, V., Rees, R., M., Barnes, A., Topp, C., F., E., Ball, B., Hoad, S., Wall, E., Mcvittie, A., Pajot, G., Matthews, R., Smith, P., \& Moxey, A. (2010). Developing greenhouse gas marginal abatement cost curves for agricultural emissions from crops and soils in the UK. Agricultural Systems, 103(4), 198209.

45. Maertens, M., \& Velde, K., V. (2017). Contract-farming in staple food chains: The case of rice in Benin. World Development, 95, 73-87.

46. Mariola, M., J. (2012). Farmers, trust, and the market solution to water pollution: The role of social embeddedness in water quality trading. Journal of Rural Studies, 28(4), 577-589.

47. Meike, W., \& Manfred, Z. (2007). Do farmers benefit from participating in specialty markets and cooperatives? The case of coffee marketing in Costa Rica. Agricultural Economics, 2, 243-248.

48. Messick, D., M., \& Kramer, R., M. (2001). Trust as a form of shallow morality. In K. S. Cook(ed.), Trust in Society, New York: Russel Sage Foundation, 2, 89-117.

49. Mishra, A., K., Kumar, A., Joshi, P. K., Souza, A., D., \& Tripathi, G. (2018). How can organic rice be a boon to smallholders? Evidence from contract farming in India. Food Policy, 75, 147-157.

50. Omotilewa, O., J., Ricker-Gilbert, J., \& Ainembabazi, J., H. (2019). Subsidies for agricultural technology adoption: Evidence from a randomized experiment with improved grain storage bags in Uganda. American Journal of Agricultural Economics. 101, 753-772.

51. Portes, A., \& Sensenbrenner, J. (1993). Embeddedness and immigration: Notes on the social determinants of economic action, American Journal of Sociology, 98(6), 1320-1350.

52. Praxmarer-carus, S. (2014). Why the proposal of a complex contract may harm or foster a partner's trust. Journal of Business Research, 67(7), 1421-1429.

53. Prazan, J. (2014). The role of agri-environmental contracts in saving biodiversity in the post-socialist Czech Republic. International Journal of the Commons, 8(1), 1-25.

54. Rangel, M., A., \& Vogl, T. (2019). Agricultural fires and health at birth. Review of Economics and Statistics. $101(4), 616-630$.

55. Rigdon, M. (2009). Trust and reciprocity in incentive contracting. Journal of Economic Behavior \& Organization, 70, 93-105.

56. Schmitz, P., W. (2019). Incomplete contracts, limited liability, and the optimality of joint ownership. Economics Letters, 183, 108558.

57. Seidel, T. (2015). Foreign market entry under incomplete contracts. World Economy, 38 (6), 899-912.

58. Shen, L., Su, C., Zheng, X., \& Zhuang, G. (2019). Contract design capability as a trust enabler in the preformation phase of interfirm relationships. Journal of Business Research, 95, 103-115.

59. Skaalsveen, K., Ingram, J., \& Urquhart, J. (2020). The role of farmers' social networks in the implementation of no-till farming practices. Agricultural Systems, 181, 102824.

60. Soullier, G., \& Moustier, P. (2018). Impacts of contract farming in domestic grain chains on farmer income and food insecurity. Contrasted evidence from Senegal. Food Policy, 79(9), 179-198.

61. Sun, X., Hu, Z., Li, M., Liu, L., Xie, Z., Li, S., \& Wang, G. (2019). Optimization of pollutant reduction system for controlling agricultural non- point-source pollution based on grey relational analysis combined with analytic hierarchy process. Journal of Environmental Management, 243, 370-380.

Page 28/30 
62. Tama, R., A., Z., Ying, L., Yu, M., Hoque, M., M., Adnan, K., M., \& Sarker, S., A. (2021). Assessing farmers' intention towards conservation agriculture by using the Extended Theory of Planned Behavior. Journal of Environmental Management, 280, 111654.

63. Tanaka, T., Camerer, C., F., \& Nguyen, Q. (2010). Risk and time preferences: Linking experimental and household survey data from Vietnam. American Economic Review, 1, 557-571.

64. Ton, G., Vellema, W., Desiere, S., Weituschat, S., \& D’Haese, M. (2018). Contract farming for improving smallholder incomes: What can we learn from effectiveness studies? World Development, 104, 46-64.

65. Tsai, J., C.-A., \& Hung, S.-Y. (2019). Examination of community identification and interpersonal trust on continuous use intention: Evidence from experienced online community members. Information \& Management, 56(4), 552-569.

66. Wang, Y., Liang, J., Yang, J., Ma, X., Li, X., Wu, J., Yang, G., Ren, G., \& Feng, Y. (2019). Analysis of the environmental behavior of farmers for non-point source pollution control and management: An integration of the theory of planned behavior and the protection motivation theory. Journal of Environmental Management, 237, 15-23.

67. Williamson, O., E. (1985). The economic institutions of capitalism. New York: Free Press.

68. Wu, J., \& Lu, J. (2019). Landscape patterns regulate non-point source nutrient pollution in an agricultural watershed. Science of the Total Environment, 669, 377-388.

69. Wuepper, D., \& Sauer, J. (2016). Explaining the performance of contract farming in Ghana: The role of selfefficacy and social capital. Food Policy, 62, 11-27.

70. Zhang, T., Yang, Y., Ni, J., \& Xie, D. (2019). Adoption behavior of cleaner production techniques to control agricultural non-point source pollution: A case study in the Three Gorges Reservoir Area. Journal of Cleaner Production, 223, 897-906.

71. Zhou, Z., Liu, J., Zeng, H., Zhang, T., \& Chen, X. (2020). How does soil pollution risk perception affect farmers' pro-environmental behavior? The role of income level. Journal of Environmental Management, $270,110806$.

72. Zou, L., Liu, Y., Wang, Y., \& Hu, X. (2020). Assessment and analysis of agricultural non-point source pollution loads in China, 1978-2017. Journal of Environmental Management, 263, 110400.

\section{Figures}




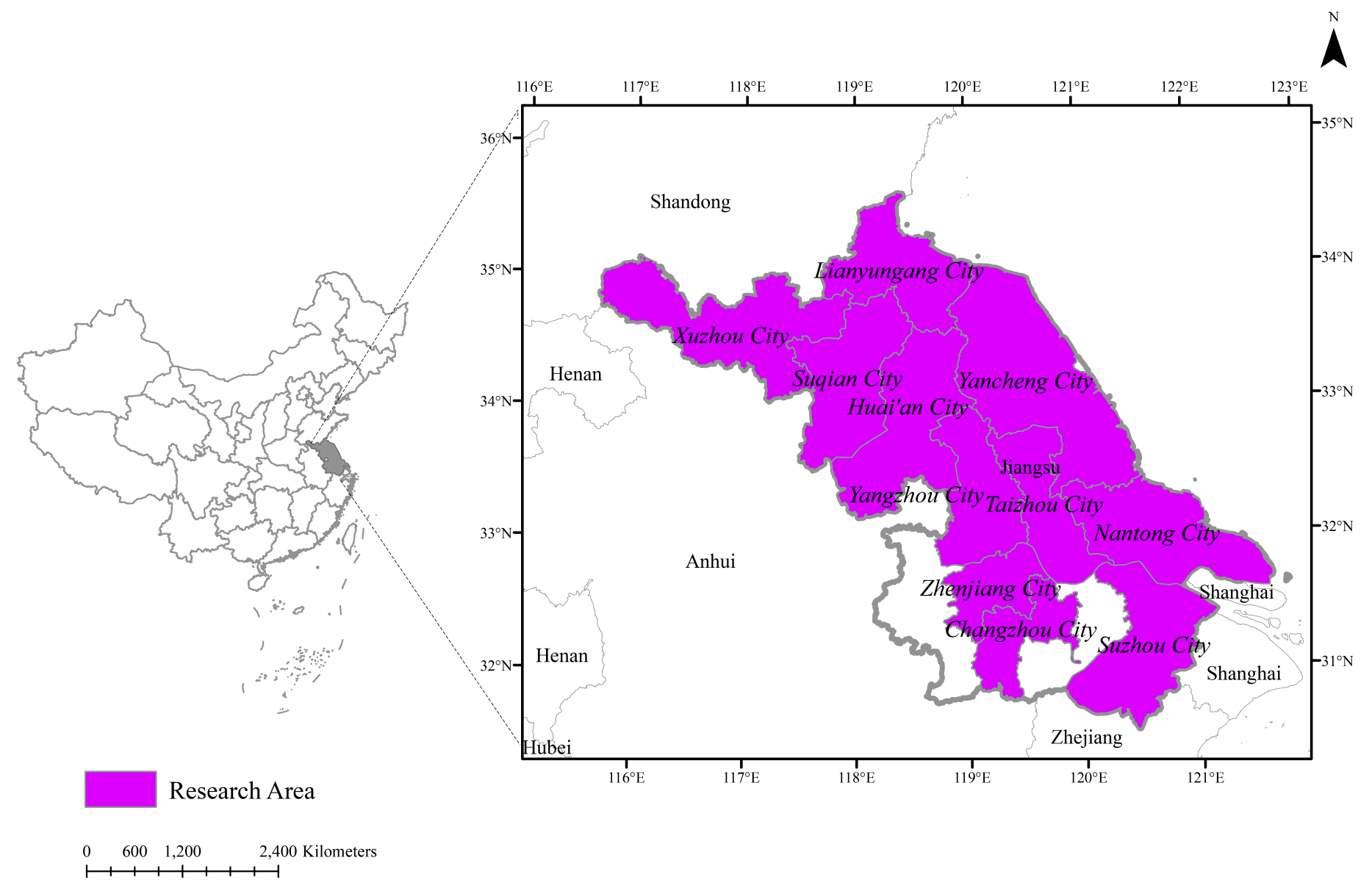

Figure 1

Field experiment sites Note: The designations employed and the presentation of the material on this map do not imply the expression of any opinion whatsoever on the part of Research Square concerning the legal status of any country, territory, city or area or of its authorities, or concerning the delimitation of its frontiers or boundaries. This map has been provided by the authors. 